\title{
Identification of a potent immunostimulatory oligodeoxynucleotide from Streptococcus thermophilus lacz
}

Takeshi SHIMOSATO ${ }^{1}$, Masanori TOHNO ${ }^{2}$, Takashi SATO ${ }^{3}$, Junko NISHIMURA ${ }^{4}$, Yasushi KAWAI ${ }^{4}$, Tadao SAITO ${ }^{4}$ and Haruki KITAZAWA ${ }^{4}$

${ }^{1}$ Fiber-Nanotech Young Researcher Empowerment Center, Shinshu University, Minamiminowa, Kamiina, Japan

${ }^{2}$ JSPS fellow, Graduate School of Dentistry, Tohoku University, Aoba, Sendai, Japan

${ }^{3}$ Graduate School of Medicine, Yokohama City University, Kanazawa, Yokohama, Japan

${ }^{4}$ Graduate School of Agricultural Science, Tohoku University, Aoba, Sendai, Japan

\section{Corresponding authors: Takeshi SHIMOSATO \& Haruki KITAZAWA}

- Takeshi SHIMOSATO: Fiber-Nanotech Young Researcher Empowerment Center, Shinshu University, 8304 Minamiminowa, Kamiina, Nagano 399-4598 Japan. E-mail: shimot@shinshu-u.ac.jp; Tel: +81-265-77-1403; Fax: $+81-265-77-1700$

- Haruki KITAZAWA: Graduate School of Agricultural Science Tohoku University 1-1 Tsutsumidori, Amamiyamachi, Aobaku, Sendai, Miyagi 981-8555, Japan. E-mail: haruki@bios.tohoku.ac.jp; Tel: +81-22-717-8713; Fax: +81-22-717-8715

Running title: Immunostimulatory ODN from S. thermophilus gene 


\section{ABSTRACT}

Immunostimulatory sequences of oligodeoxynucleotides (ODNs), such as CpG ODNs, are potent stimulators of innate immunity. Here, we identified a strong immunostimulatory CpG ODN, which we named MsST, from the lac Z gene of Streptococcus thermophilus ATCC19258, and we evaluated its immune functions. In in vitro studies, MsST had a similar ability as the murine prototype CpG ODN 1555 to induce inflammatory cytokine production and cell proliferation. In mouse splenocytes, MsST increased the number of $C D 80^{+} \mathrm{CD} 11 \mathrm{c}^{+}$and $\mathrm{CD} 6^{+} \mathrm{CD} 11 \mathrm{c}^{+}$dendritic cells and $\mathrm{CD} 4^{+} \mathrm{CD} 25^{+}$regulatory $\mathrm{T}$ cells. We also analyzed the effects of MsST on the expression of regulatory cytokines by real-time quantitative PCR. MsST was more potent at inducing interleukin-10 expression than the ODN control 1612, indicating that MsST can augment the regulatory $\mathrm{T}$ cell response via Toll-like receptor 9 , which plays an important role in suppressing $T$ helper type 2 responses. These results suggest that $S$. thermophilus, whose genes include a strong Immunostimulatory sequence-ODN, is a good candidate for a starter culture to develop new physiologically functional foods and feeds.

KEYWORDS: lacZ, ODN, regulatory T cell, Streptococcus thermophilus.

\section{INTRODUCTION}

Modification of the intestinal flora early in life by administration of probiotics such as lactic acid bacteria (LAB) may help prevent atopic disease (Kalliomaki et al. 2003). Experimental studies have found that probiotic LAB exert strain-specific anti-allergic effects on intestinal epithelial cells and immune cells. In a recent study, it was suggested that Streptococcus (S.) thermophilus or its cell components enhance intestinal barrier capacity and T helper type 1 (Th1) immune responses, highlighting the involvement of LAB-derived components in host defense (Menard et al. 2005). S. thermophilus is generally recognized as a 
safe type of bacteria and is commonly used in the production of yogurt, and its fermented products are expected to be functional foods that can contribute to health promotion by regulating immunity in gut-associated lymphoid tissues (GALTs).

It has been reported that B cell mitogenicity is induced by pathogenic bacterial DNA and yeast DNA. These DNAs consist of CpG motifs (Krieg et al. 1995), which are typical ligands for Toll-like receptor (TLR) 9. In our previous studies, we identified several immunostimulatory (ISS)-oligodeoxynucleotides (ODNs) from the genomic DNA of LAB and various bifidobacterium, including Lactobacillus rhamnosus GG, L. gasseri JCM1131', L. gasseri OLL2716, L. delbrueckii ssp. bulgaricus NIAI B6, and Bifidobacterium longum BB536. These ISS-ODNs immunoregulate splenocytes and the immunocompetent cells from GALTs (Kitazawa et al. 2001, 2003; Iliev et al. 2005; Shimosato et al. 2005a; Takahashi et al. 2006). These findings prompted us to investigate the immunoregulatory activities of genomic DNA, including ISS-ODNs from $S$. thermophilus. In this study, we focused on the ISS-ODNs from S. thermophilus and investigated their TLR9-mediated immunoregulatory effects on regulatory T cells.

\section{MATERIALS \& METHODS}

\section{Mice}

Female BALB/c mice were obtained from the National Cancer Institute (Frederick, MD) and studied at 6 - 10 weeks of age. TLR $9^{-/-}$knockout (KO) mice were kindly provided by Dr. S. Akira (Osaka University, Osaka, Japan) (Hemmi et al. 2000). All mice were housed in plastic cages at room temperature and provided food ad libitum. The mice were handled in accordance with animal care and use guidelines of Tohoku University. 


\section{Reagents}

Endotoxin-free phosphorothioate ODNs were synthesized by OPERON (Tokyo, Japan). The ODNs were reconstituted in endotoxin-free water and passed through a $0.22 \mu \mathrm{m}$ pore microfilter (Nihon Millipore K.K., Tokyo, Japan). Cells were stimulated with an equimolar mixture of CpG ODN 1555 (5'-GCTAGACGTTAGCGT-3'), control ODN GpC 1612 (5'-GCTAGAGCTTAGGCT-3') (Klaschik et al. 2007), or MsST (5'-CAGGACGTTGTATCACTGAA-3'). The ODNs were confirmed to be free of detectable endotoxin using a Limulus amebocyte lysate kit (Seikagaku, Tokyo, Japan) according to the manufacturer's instructions. Lipopolysaccharide (LPS) from Escherichia coli O111:B4 was purchased from Sigma-Aldrich (St. Louis, MO, USA).

\section{Cells and cell cultures}

Mouse splenocytes (mSps) were prepared using standard methods (Iliev et al. 2005). Cells were cultured in triplicate wells of a 24-well plate (Nalge Nunc International K.K. Tokyo, Japan) at a final concentration of $2 \times 10^{6}$ cells/well (total 1mL/well) in complete RPMI 1640 medium (Sigma) supplemented with 10\% fetal calf serum (FCS; Sigma), $100 \mathrm{U} / \mathrm{mL}$ penicillin, $100 \mu \mathrm{g} / \mathrm{mL}$ streptomycin, $25 \mathrm{mmol} / \mathrm{L}$ HEPES, $1.0 \mathrm{mmol} / \mathrm{L}$ sodium pyruvate, nonessential amino acids, and 0.0035\% 2-mercaptoethanol (Sato et al. 2008).

\section{Enzyme-linked immunosorbent assay}

IL-6 levels in culture supernatants were measured by enzyme-linked immunosorbent assay. IL-6 monoclonal Abs were purchased from BD Pharmingen (San Diego, CA, USA). Ninety-six-well Immulon H2B plates (Thermo LabSystems, MA, USA) were coated with capture cytokine-specific Abs and then blocked with phosphate-buffered saline containing $1 \%$ bovine serum 
albumin. Culture supernatants were added, and bound cytokines detected by the addition of biotin-labeled secondary Ab, followed by phosphatase-conjugated avidin and a phosphatase-specific colorimetric substrate. Standard curves were generated using recombinant cytokines purchased from R\&D Systems.

\section{Mitogenicity assay}

The mitogenicity assay was conducted as previously described (Kitazawa et al. 2001). Briefly, mSps $\left(2 \times 10^{5} /\right.$ well) were placed in each well of a 96 -well microplate (Costar; Corning Inc, Corning, NY, USA) and incubated in an atmosphere containing $5 \% \mathrm{CO}_{2}$ at $37^{\circ} \mathrm{C}$ for $48 \mathrm{~h}$ in triplicate cultures of $100 \mu \mathrm{L}$ in complete RPMI 1640 medium supplemented with 2\% FCS, $1.0 \mu \mathrm{mol} / \mathrm{L}$ ODNs, and $20 \mathrm{ng} / \mathrm{mL}$ LPS. In the final $16 \mathrm{~h}$ of culture, the cells were radiolabeled with $9.25 \mathrm{kBq} /$ well of [methyl- ${ }^{3} \mathrm{H}$ ]-thymidine (Amersham Life Science International PLC, Buckinghamshire, UK). Next, the cells were harvested on glass fiber filters (Packard Bioscience, Canberra, Australia). The bound [methyl- ${ }^{3} \mathrm{H}$ ]- thymidine was counted in a liquid scintillation counter (Beckman Instruments, Palo Alto, CA, USA). Results are presented as the proliferation index, calculated as follows: proliferation index $=[$ (counts per minute in treated cultures)-(background counts per minute) $] /[($ counts per minute in control cultures)-(background counts per minute)].

\section{Flow cytometric analysis}

The mSps $\left(2 \times 10^{6}\right.$ cells/well $)$ were stimulated with $1.0 \mu \mathrm{M}$ ODNs for $24 \mathrm{~h}$. After stimulation, the cells were washed extensively in washing buffer (phosphate-buffered saline containing $2 \%$ FCS $+0.01 \%$ sodium azide) and sequentially reacted with the combinations of antibodies (Abs) as follows: (i) phycoeryhtrin (PE)-conjugated rat anti-mouse CD80 or CD86 Ab (BD 
Pharmingen, San Diego, CA, USA), biotinylated Armenian hamster anti-mouse $\mathrm{CD} 11 \mathrm{c} \mathrm{Ab}$ (BD Pharmingen) for $30 \mathrm{~min}$ at $4^{\circ} \mathrm{C}$ in the dark and then immunostained with PE-Cy5-conjugated streptavidin (eBioscience, San Diego, CA, USA) for anti-CD11c Ab; (ii) FITC- conjugated rat anti-mouse CD4 and PE-conjugated rat anti-mouse CD25 Ab (BD Pharmingen) for 30 min at $4^{\circ} \mathrm{C}$ in the dark. After washing twice with washing buffer, cells were fixed with $1 \%$ paraformaldehyde for 15 min at room temperature. Expression of cell surface antigens was analyzed (20,000 cells) with a FACScalibur ${ }^{\mathrm{TM}}$ using CELLQuest software (BD Bioscience, Tokyo, Japan).

\section{Real-time quantitative PCR analysis}

Total RNA was isolated from ODN-stimulated mSps. Total RNA was then treated with DNAse I, RNAse-free (Roche, Lewes, UK) for 10 min at $37^{\circ} \mathrm{C}$ and heat-inactivated at $70^{\circ} \mathrm{C}$ for 15 min (Katoh et al. 2004). The cDNAs were prepared by reverse transcription from $1 \mu \mathrm{g}$ of total RNA using a PrimeScript ${ }^{\circledR}$ RT reagent Kit (Takara Bio Inc., Tokyo, Japan). An equivalent volume of the cDNA solution was used for quantification of various cytokine cDNAs by real-time quantitative PCR using a Thermal Cycler Dice ${ }^{\circledR}$ Real Time System (Takara Bio Inc.). Fluorescent real-time quantitative PCR reactions were performed on SYBR Premix Ex Taq (Takara Bio Inc.) using specific primers, with each reaction containing $5 \mathrm{ng}$ of cDNA in $25 \mu \mathrm{L}$. The $\beta$-actin and Interleukin (IL)-10 primers were purchased from Takara Bio Inc. The PCR cycling conditions were $10 \mathrm{~s}$ at $95^{\circ} \mathrm{C}$, followed by 40 cycles of $5 \mathrm{~s}$ at $95^{\circ} \mathrm{C}$, and $30 \mathrm{~s}$ at $60^{\circ} \mathrm{C}$. In the control tubes, poly (A)+RNA samples were used as templates to check for the presence of contaminating genomic DNA. The sensitivity of the reaction and amplification of contaminant products such as primer dimers were evaluated by amplifying serial dilutions of the cDNA. 


\section{Statistical analysis}

The significance of differences between the mean and control values was assessed by analysis of variance.

\section{RESULTS}

\section{MsST induces an inflammatory response in splenocytes via TLR9}

A search of MsST in the S. thermophilius $\beta$-galactosidase gene (accession no. M63636) shows that it includes a mouse prototype CpG motif (5'-ACGT-3'). Titration studies were performed to determine the optimal concentration of immunostimulatory CpG ODN in our experimental system. The positive control, CpG ODN 1555, induced high levels of IL-6 production (Fig. 1A). IL-6 production was observed in the wild-type mSps stimulated with not only CpG ODN 1555 but also MsST, whereas the negative control ODN 1612 had little effect (Fig. 1B). The splenocytes from TLR9 KO mice did not produce IL-6 when stimulated with CpG ODN 1555 or MsST (Fig. 1C). These results indicated that MsST can induce IL-6 production via TLR9.

\section{Strong mitogenic activity of MsST}

To investigate the immunostimulatory activity of MsST from S. thermophilus ATCC19258, we examined its mitogenic activity in mSps. The stimulation indices of MsST, CpG1555, and GpC1612 were $3.76 \pm 0.68,3.53 \pm 0.10$, and $1.18 \pm$ 0.14 , respectively (Fig. 2). Thus, the mitogenic activity of MsST was comparable to or slightly greater than that of CpG1555. These results suggest that MsST can induce a strong immune response via TLR9 in splenocytes, which express a high level of TLR9 (Shimosato et al. 2003).

\section{MsST induces costimulatory molecules in dendritic cells (DCs)}

We next examined the surface expression of CD80 and CD86 on CD11 ${ }^{+}$DCs 
after treatment with $1.0 \mu \mathrm{mol} / \mathrm{L}$ of the various ODNs for $24 \mathrm{~h}$ (Fig. 3). The expression of CD80 and CD86 on CD11c ${ }^{+}$DCs was higher following stimulation with MsST (Fig. 3A, B) or 1555 (Fig. 3D, E) than with 1612 (Fig. 3C, F). We also analyzed the fraction of $C D 11 c^{+}$cells that were $\mathrm{CD}^{+} 0^{+}$or $\mathrm{CD} 6^{+}$after a $24-\mathrm{h}$ stimulation (Fig. 3G, H). The fractions were higher following stimulation with MsST (CD80, 72.58\%; CD86, 79.34\%) and 1555 (CD80, 73.72\%; CD86, 80.01\%) than the control ODN (CD80, 31.86\%, CD86: 44.57\%). These results suggest that MsST up-regulates the surface expression of CD80 and CD86 on CD11c ${ }^{+}$DCs.

\section{Expression analysis of $\mathrm{CD} 4^{+} \mathrm{CD} 25^{+}$regulatory $\mathrm{T}$ cells}

The CD4+CD25+ T lymphocyte subpopulation is known to include the regulatory $\mathrm{T}$ ( $\mathrm{T}$ reg) cells with immunosuppressive activity (Wing et al. 2005). We used flow cytometry to investigate the effect of MsST on the CD4+CD25+ T reg cell population in vitro. Stimulation of mSps with MsST and 1555 significantly increased the ratio of CD4+CD25+ to total CD4+ cells (Fig. 4).

\section{Induction of IL-10 mRNA by MsST}

We examined the ability of ODNs to induce IL-10 gene expression in mSps by real-time quantitative PCR (Fig. 5). We found that MsST strongly induces the expression of IL-10. The 1555 ODN induced a similar level of IL-10 expression. In contrast, the negative control 1612 ODN did not increase IL-10 expression. Sequencing analysis showed that the amplified cDNAs were identical to various cytokine genes.

\section{DISCUSSION}

TLR9 has been identified as a specific receptor for CpG ODNs (Hemmi et al. 2000), and the possible signaling pathways for TLR9, mediated by myeloid 
differentiation factor 88, have been elucidated (Akira et al. 2001). CpG ODN is an extremely potent stimulator of DCs and macrophages and causes the induction of Th1-like cytokines, such as IL-6 and IL-12 (Wagner et al. 2004). This suggests that CpG ODNs would be highly effective Th1-like vaccine adjuvants and could be developed for use in DNA-based vaccines (Krieg. 2006). Some trials have already evaluated CpG ODNs as adjuvants for protein antigens (Eastcott et al. 2001; McCluskie et al. 2001). Also, a recent study demonstrated that CpG ODNs have immunostimulatory effects on leukocytes from humans and vertebrates other than mice (Krieg, 2006). In addition, we previously reported that the CpG ODNs from probiotic LAB can immunopotentiate splenic $B$ cells and immunocompetent cells in GALTs such as Peyer's patches (Kitazawa et al. 2001, 2003; Iliev et al. 2005; Shimosato et al. 2005a, 2006). We also found that GALTs strongly express TLR2 and TLR9 (Shimosato et al. 2005b; Tohno et al. 2007). These findings suggest that genomic DNA and CpG ODNs, such as MsST, stimulate intestinal immune responses via TLR9.

In the present study, we identified a strong immunostimulatory CpG ODN, MsST. The activity of MsST is comparable to that of the prototype mouse CpG ODN 1555. MsST significantly enhanced IL-6 production and mitogenesis of mSps and induced the expression of CD80 and CD86 by CD11 ${ }^{+}$DCs. In addition, the number of $\mathrm{CD} 4^{+} \mathrm{CD} 25^{+}$cells was greatly increased by treatment with MsST. We also observed a significant up-regulation of IL-10 expression by stimulation with MsST. The experiments using TLR9 KO mice indicated that MsST induces immune responses through the TLR9-mediated signaling pathway.

Recently, induction of IL-10 has been proposed as an important mechanism of immunotherapy (Kitagaki et al. 2002). IL-10 production is reduced in patients with asthma compared with nonasthmatic control subjects (Borish et al. 1996). In mouse studies, it was shown that IL-10 suppresses the development of 
eosinophilic inflammation in the airways (Van et al. 2000). Also, it has been recently shown that ISS-ODN can activate plasmacytoid DCs, inducing the differentiation of T reg (Moseman et al. 2004; Iliev et al. 2008). Therefore, MsST may activate subsets of plasmacytoid DCs, resulting in the induction of a predominant Th1 response via the activation of $\mathrm{T}$ reg. These findings correspond well with our observation that MsST enhances IL-10 expression and increases the numbers of $\mathrm{CD} 4^{+} \mathrm{CD} 25^{+} \mathrm{T}$ reg cells in mSps. Thus, the current results suggest that MsST may be useful in developing immune functional foods or feeds as Th1-dominated prophylactics.

In conclusion, we identified a novel immunoregulatory CpG ODN from $S$. thermophilus that activates the TLR9-mediated signaling pathway.

Understanding how the TLR9 signaling pathway mediates the immunoregulatory activity of MsST should help in the development of physiologically functional foods or feeds that specifically target innate and adaptive immune responses. For that purpose, a possible mechanism of immunomodulation by MsST in peyer's patches, a part of the gut-associated lymphoid tissue, which is known to play an important role in mucosal immunity, is now in progress.

\section{Acknowledgements}

Financial support for this study was provided by the Special Coordination Funds for Promoting Science and Technology of the Ministry of Education, Culture, Sports, Science and Technology, the Japanese Government. This study was also partly supported by a Grant-in-Aid for Young Scientists (B) (No. 20780238) from the Japan Society for the Promotion of Science (JSPS), Shinshu Foundation for Promotion of Agricultural and Forest Science and Hokuto Foundation for Bioscience to T.S. and a Grant-in-Aid for Scientific Research (B)(2) (No. 18380158) from the Japan Society for the Promotion of Science to H.K. Also, M.T. was supported by a JSPS PD research fellowship 
(Research Fellowships for Young Scientists Program).

\section{REFERENCES}

- Akira S, Takeda K, Kaisho T. 2001.Toll-like receptors: critical proteins linking innate and acquired immunity. Nature Immunology 2, 675-680.

- Borish L, Aarons A, Rumbyrt J, Cvietusa P, Negri J, Wenzel S. 1996. Interleukin-10 regulation in normal subjects and patients with asthma. The Journal of Allergy and Clinical Immunology 97,1288-1296.

- Eastcott JW, Holmberg CJ, Dewhirst FE, Esch TR, Smith DJ, Taubman MA. 2001. Oligonucleotide containing CpG motifs enhances immune response to mucosally or systemically administered tetanus toxoid. Vaccine 19,1636-1642.

- Hemmi H, Takeuchi O, Kawai T, Kaisho T, Sato S, Sanjo H, Matsumoto M, Hoshino K, Wagner H, Takeda K, Akira S. 2000. A Toll-like receptor recognizes bacterial DNA. Nature 408, 740-745.

- Kalliomaki M, Salminen S, Poussa T, Arvilommi H, Isolauri E. 2003. Probiotics and prevention of atopic disease: 4-year follow-up of a randomised placebo-controlled trial. The Lancet 361, 1869-1871.

- Katoh S, Kitazawa H, Shimosato T, Tohno M, Kawai Y, Saito T. 2004. Cloning and characterization of Swine interleukin-17, preferentially expressed in the intestines. Journal of Interferon \& Cytokine Research 24, 553-559.

- Kitagaki K, Jain VV, Businga TR, Hussain I, Kline JN. 2002. Immunomodulatory effects of $\mathrm{CpG}$ oligodeoxynucleotides on established th2 responses. Clinical and Diagnostic Laboratory Immunology $\mathbf{9}$, 1260-1269.

- Kitazawa H, Ueha S, Itoh S, Watanabe H, Konno K, Kawai Y, Saito T, Itoh T, 
Yamaguchi T. 2001. AT oligonucleotides inducing B lymphocyte activation exist in probiotic Lactobacillus gasseri. International Journal of Food Microbiology 65, 149-162.

- Kitazawa H, Watanabe H, Shimosato T, Kawai Y, Itoh T, Saito T. 2003. Immunostimulatory oligonucleotide, CpG-like motif exists in Lactobacillus delbrueckii ssp. bulgaricus NIAI B6. International Journal of Food Microbiology 85, 11-21.

- Klaschik S, Gursel I, Klinman DM. 2007. CpG-mediated changes in gene expression in murine spleen cells identified by microarray analysis. Molecular Immunology 44, 1095-1104.

- Krieg AM, Yi AK, Matson S, Waldschmidt TJ, Bishop GA, Teasdale R, Koretzky GA, Klinman DM. 1995. CpG motifs in bacterial DNA trigger direct B-cell activation. Nature 374, 546-549.

- Krieg AM. 2006. Therapeutic potential of Toll-like receptor 9 activation. Nature Reviews Drug Discovery 5, 471-484.

- Iliev ID, Kitazawa H, Shimosato T, Katoh S, Saito T. 2005. Strong immunostimulation in murine immune cells by Lactobacillus rhamnosus GG DNA containing novel oligodeoxynucleotide pattern. Cellular Microbiology 7, 403-414.

- Iliev ID, Tohno M, Kurosaki D, Shimosato T, He F, Hosoda M, Sait s o T, Kitazawa H. 2008. Immunostimulatory oligodeoxynucleotide containing TTTCGTTT motif from Lactobacillus rhamnosus GG DNA potentially suppresses OVA-specific IgE production in mice. Scandinavian Journal of Immunology 67, 370-376.

- McCluskie MJ, Weeratna RD, Davis HL. 2001. The potential of oligodeoxynucleotides as mucosal and parenteral adjuvants. Vaccine 19, 2657-2660.

- Menard S, Laharie D, Asensio C, Vidal-Martinez T, Candalh C, Rullier A, 
Zerbib F, Megraud F, Matysiak-Budnik T, Heyman M. 2005. Bifidobacterium breve and Streptococcus thermophilus secretion products enhance T helper 1 immune response and intestinal barrier in mice. Experimental Biology and Medicine 230, 749-756.

- Moseman EA, Liang X, Dawson AJ, Panoskaltsis-Mortari A, Krieg AM, Liu YJ, Blazar BR, Chen W. 2004. Human plasmacytoid dendritic cells activated by $\mathrm{CpG}$ oligodeoxynucleotides induce the generation of CD4+ CD25+ regulatory T cells. The Journal of Immunology 173, 4433-4442.

- Sato T, Shimosato T, Alvord WG, Klinman DM. 2008. Suppressive oligodeoxynucleotides inhibit silica-induced pulmonary inflammation. The Journal of Immunology 180, 7648-7654.

- Shimosato T, Kitazawa H, Katoh S, Tomioka Y, Karima R, Ueha S, Kawai Y, Hishinuma T, Matsushima K, Saito T. 2003. Swine Toll-like receptor 9 recognizes CpG motifs of human cell stimulant. Biochimica et Biophysica Acta 1627, 56-61.

- Shimosato T, Kitazawa H, Tohno M, Katoh S, Iliev ID, Nagasawa C, Kawai Y, Saito T. 2005a. Augmentation of $\mathrm{T}_{\mathrm{H}}-1$ type response by immunoactive AT oligonucleotide from lactic acid bacteria via Toll-like receptor 9 signaling. Biochemical and Biophysical Research Communication 326, 782-787.

- Shimosato T, Tohno M, Kitazawa H, Katoh S, Watanabe K, Kawai Y, Aso H, Yamaguchi T, Saito T. 2005b. Toll-like receptor 9 is expressed on follicle-associated epithelia containing M cells in swine Peyer's patches. Immunology Letters 98, 83-89.

- Shimosato T, Kimura T, Tohno M, Iliev ID, Katoh S, Itoh Y, Kawai Y, Sasaki T, Saito T, Kitazawa H. 2006. Strong immunostimulatory activity of AT-oligodeoxynucleotide requires a six-base loop with a self-stabilized 5'-C...G-3' stem structure. Cellular Microbiology 8, 485-95.

- Takahashi N, Kitazawa H, Iwabuchi N, Xiao JZ, Miyaji K, Iwatsuki K, Saito T. 
2006. Oral administration of an immunostimulatory DNA sequence from Bifidobacterium longum improves Th1/Th2 balance in a murine model. Bioscience Biotechnology and Biochemistry 70, 2013-2017.

- Tohno M, Shimosato T, Kawai Y Aso H, Ikegami S, Taketomo N, Saito T, Kitazawa H. 2007. An advanced molecular immunoassay system for immunobiotic lactic acid bacteria using a transfectant of Toll-like receptor 2 . Animal Science Journal 8, 195-205.

- Van Scott MR, Justice JP, Bradfield JF, Enright E, Sigounas A, Sur S.2000. IL-10 reduces Th2 cytokine production and eosinophilia but augments airway reactivity in allergic mice. American Journal of Physiology $\mathbf{2 7 8 ,}$ 667-74.

- Wagner M, Poeck H, Jahrsdoerfer B, Rothenfusser S, Prell D, Bohle B, Tuma E, Giese T, Ellwart JW, Endres S, Hartmann G. 2004. IL-12p70-dependent Th1 induction by human B cells requires combined activation with CD40 ligand and CpG DNA. The Journal of Immunology $\mathbf{1 7 2 ,}$ 954-963.

- Wing K, Suri-Payer E, Rudin A. 2005. CD4 ${ }^{+} \mathrm{CD} 25^{+}$-regulatory T cells from mouse to man. Scandinavian Journal of Immunology 62, 1-15.

\section{Figure legends}

Figure 1 CpG ODN 1555, known for its strong immunostimulatory activity in $\mathrm{mSps}$, was used as a positive control to determine the optimal amount of ODN (A). IL-6 production in wild-type mSps (B) and TLR9 KO mSps (C) stimulated with ODNs and LPS. Supernatants from stimulated cells were collected, and the concentration of IL-6 was measured by ELISA. Columns represent the mean concentrations $(\mathrm{ng} / \mathrm{mL})$, and error bars indicate the standard errors. ${ }^{*} P<0.01$ 
and ${ }^{*} P<0.05$ vs. identically treated cells cultured in the presence of control ODN 1612.

Figure 2 Mitogenic activity of ODNs toward mSps. Mitogenic activity was examined in the presence of $1 \mu \mathrm{mol} / \mathrm{L}$ ODN. Values represent means, and error bars indicate the standard deviations. Each experiment was repeated three times. ${ }^{*} P<0.01$ and ${ }^{\star} P<0.05$ vs. cells cultured in the absence of ODNs.

Figure 3 Expression of CD80 (A, B, C) and CD86 (D, E, F) on mouse DCs following stimulation with ODNs for $24 \mathrm{~h}$. Cells were stimulated with MsST (A, D), 1555 (B, E), or 1612 (C, F) and then sorted into CD11 $\mathrm{c}^{+} \mathrm{DCs}$. The percent $\mathrm{CD}^{2} 0^{+}$and $\mathrm{CD} 6^{+}$cells was determined in each group. (G, $\left.\mathrm{H}\right)$ The mean percentage of $\mathrm{CD}^{\circ} 0^{+} \mathrm{CD} 11 \mathrm{c}^{+} / \mathrm{CD} 11 \mathrm{c}^{+}(\mathrm{G})$ and $\mathrm{CD} 6^{+} \mathrm{CD} 11 \mathrm{c}^{+} / \mathrm{CD} 11 \mathrm{c}^{+}(\mathrm{H})$ following stimulation with ODNs.

Figure 4 The percentage of $C D 4^{+} \mathrm{CD} 25^{+} \mathrm{T}$ cells was gated by plotting CD4+ vs. CD25+ T cells (Gate R2). mSps were stimulated with MsST (A, B), 1555 (C, D), or $1612(\mathrm{E}, \mathrm{F})$ for $24 \mathrm{~h}$ and then sorted into $\mathrm{CD} 4^{+} \mathrm{T}$ cells (Gate R2). The percent of $\mathrm{CD} 25^{+}$cells was determined in each group. (G) Mean percentage of $\mathrm{CD} 4^{+} \mathrm{CD} 25^{+} / \mathrm{CD}^{+}$following stimulation with ODNs. Similar results were obtained from at least three different mice.

Figure 5 Comparison of IL-10 mRNA expression by real-time quantitative PCR. Results are expressed as the relative mRNA index based on the estimation of the copy numbers and compared to 1612-stimulated cells following normalization of the cytokine mRNA copy numbers by the $\beta$-actin mRNA copy numbers. Columns represent the mean relative index, and error bars indicate the standard errors. ${ }^{*} P<0.01$ vs. identically treated cells cultured in the 
presence of control ODN 1612. The assays were performed at least three times, and representative results are presented. 
Fig.1

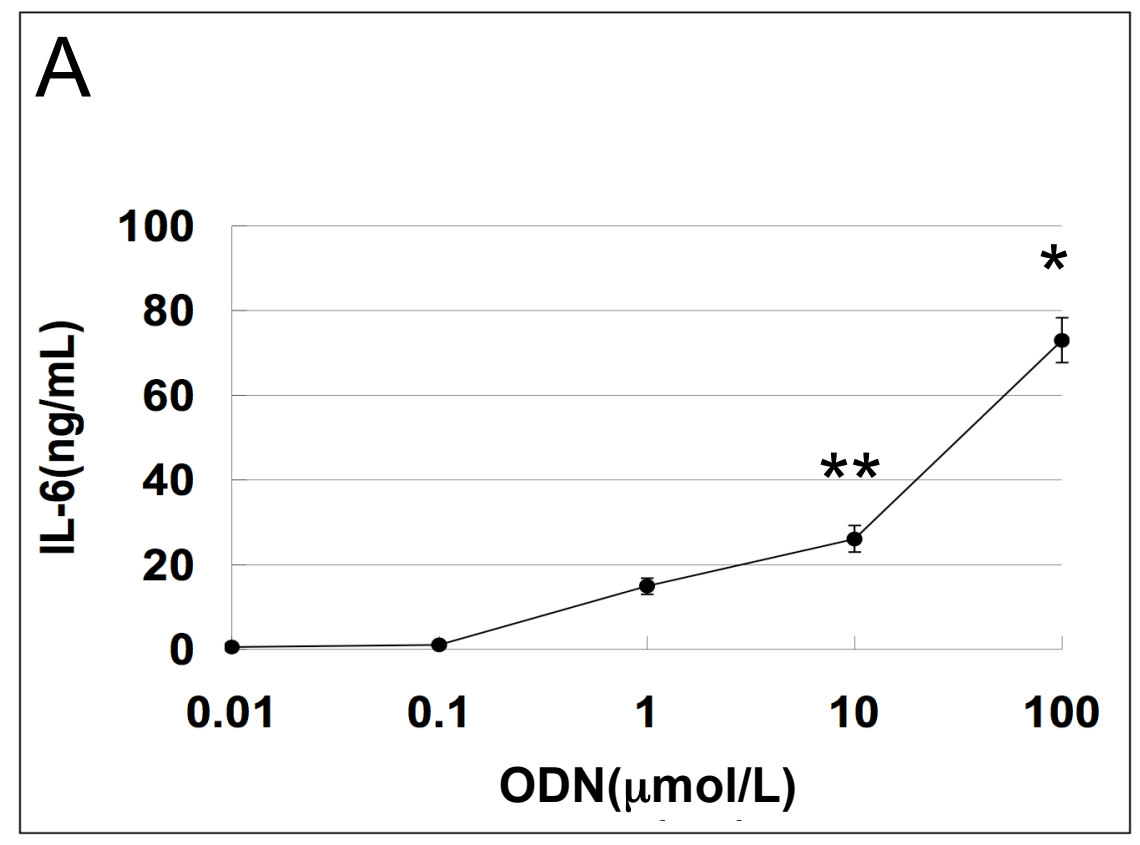

\section{B}

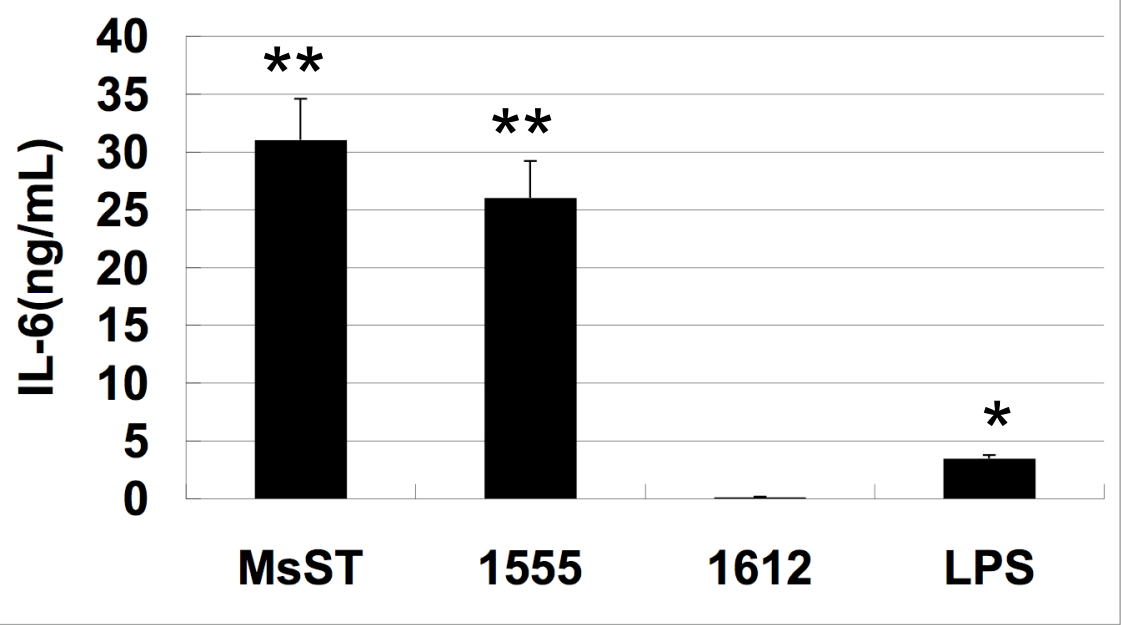

C

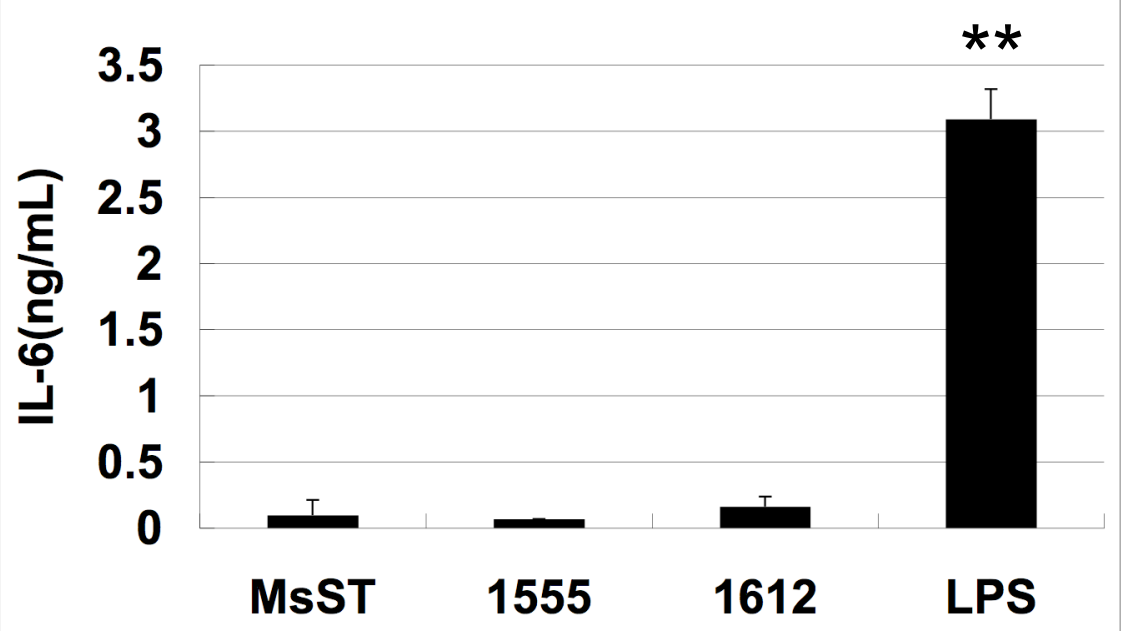


Fig.2

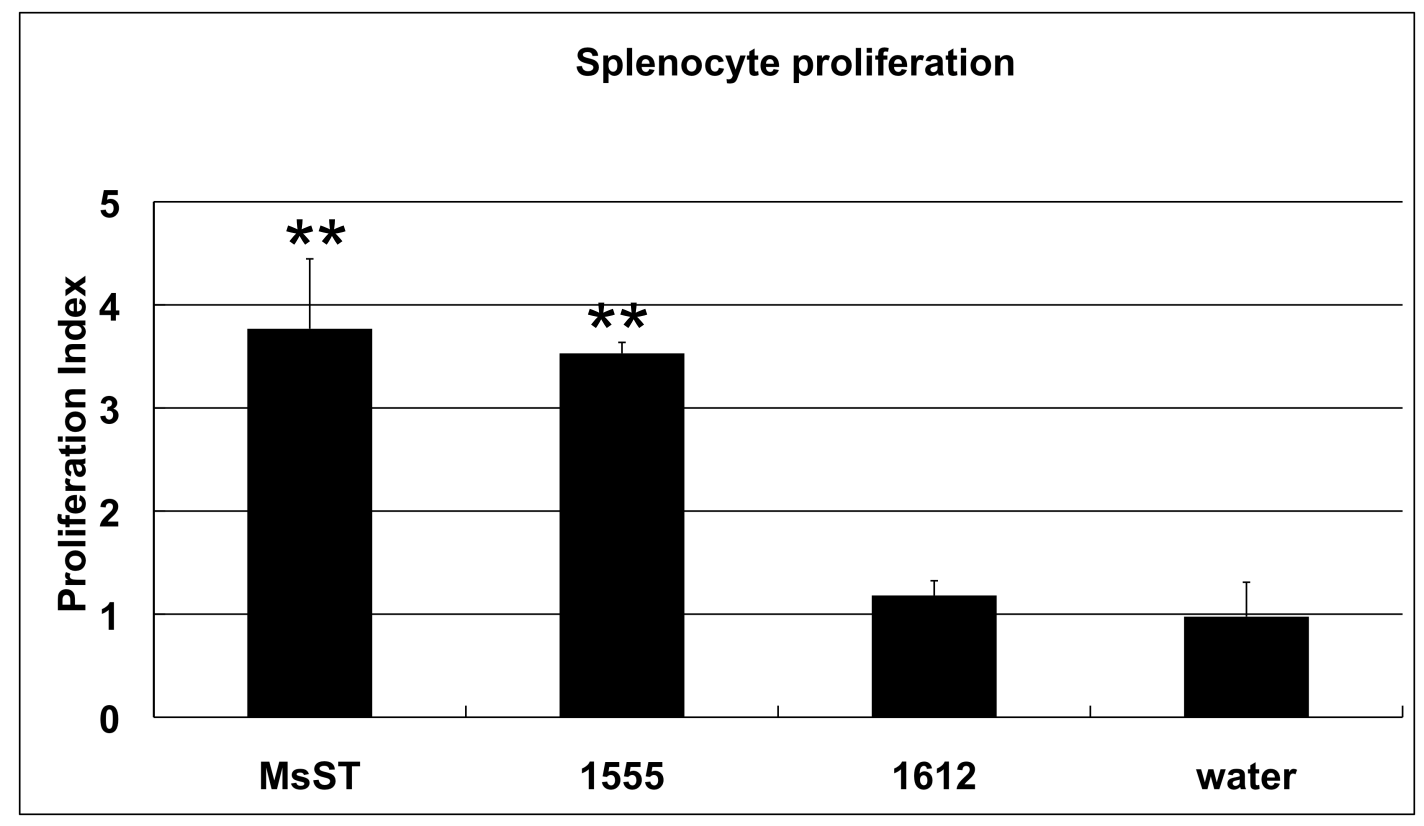


Fig.3

A

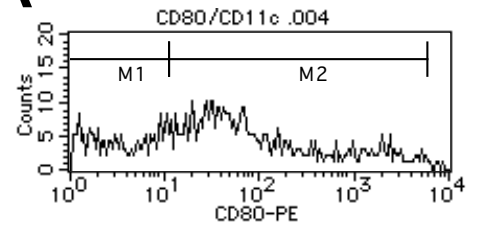

D

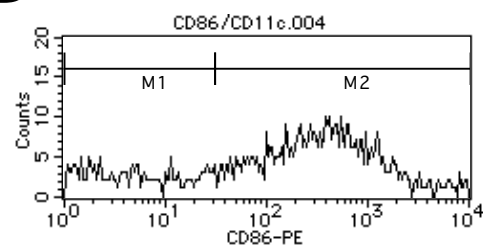

B

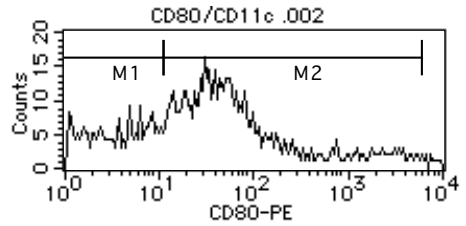

E

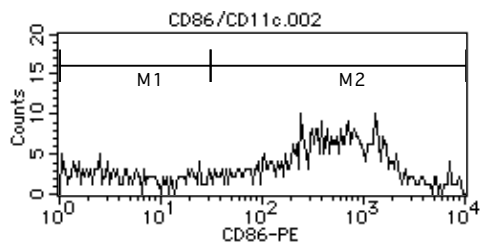

C

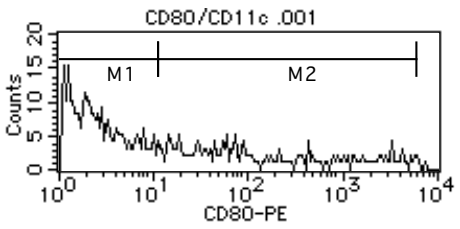

F

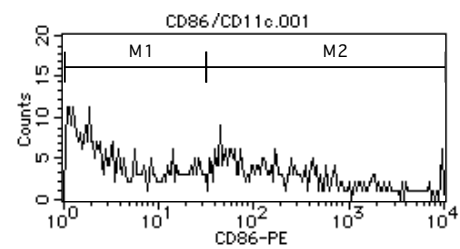

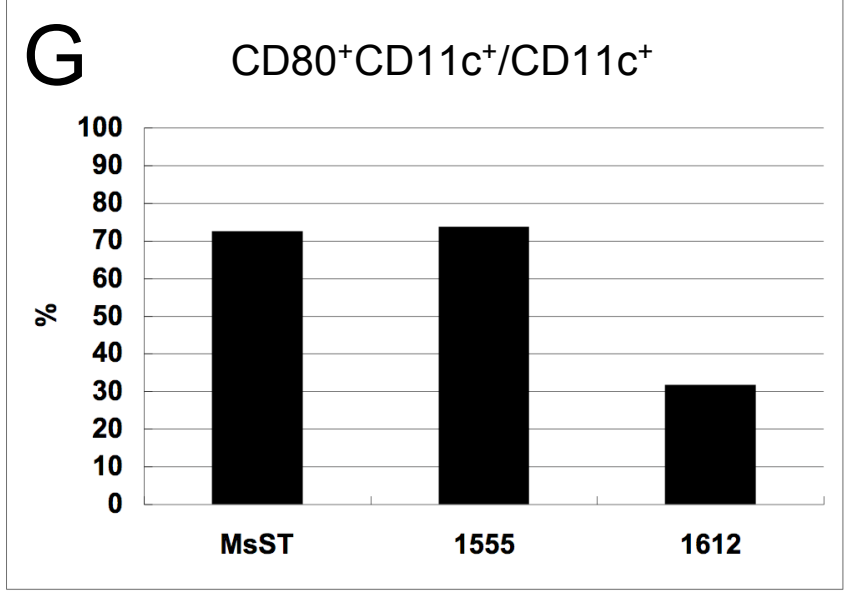

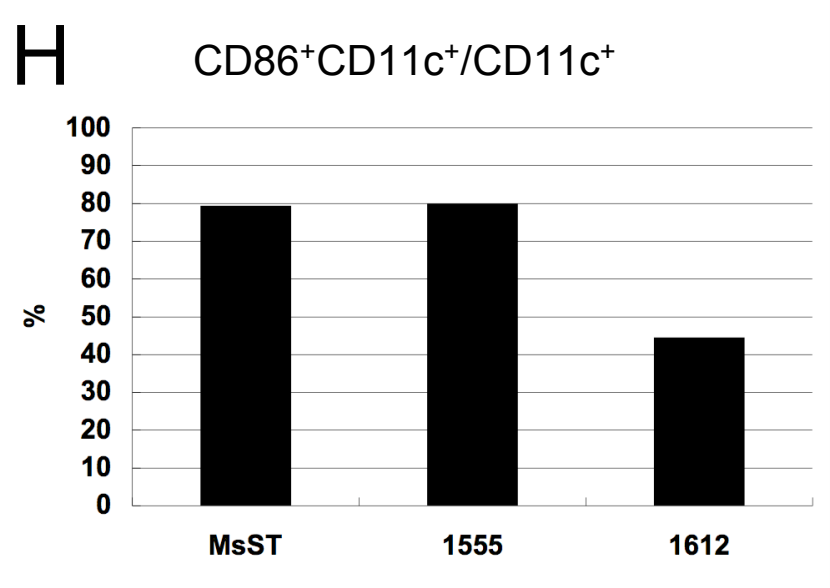


Fig.4

A

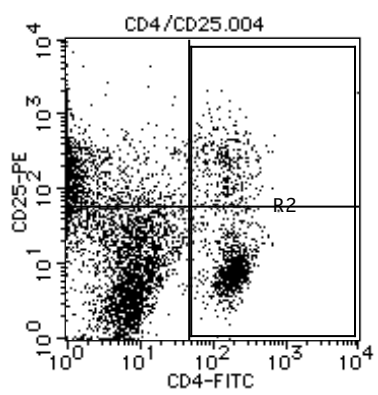

C

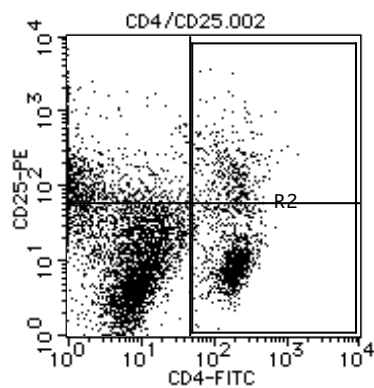

E

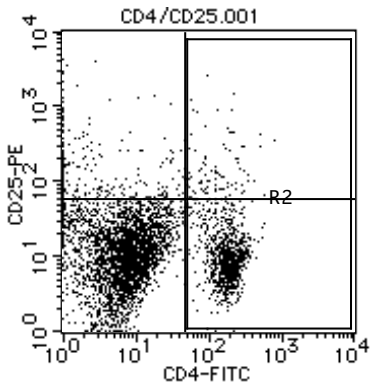

B

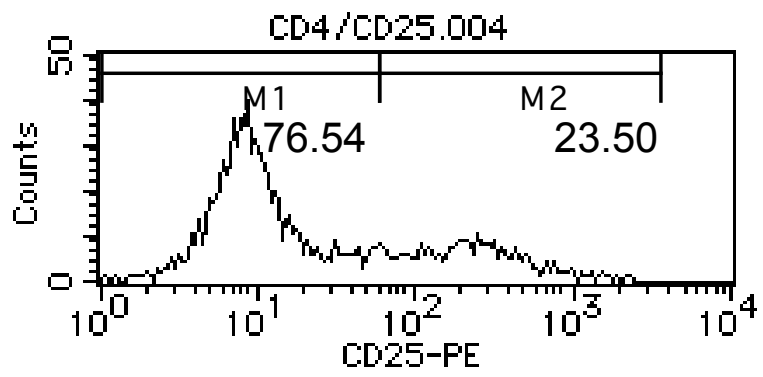

D

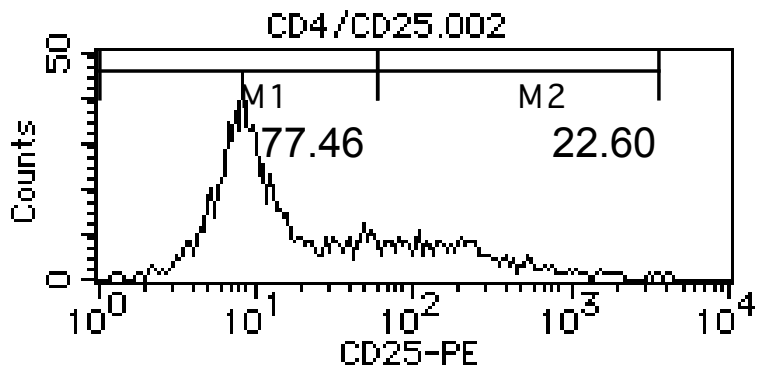

F

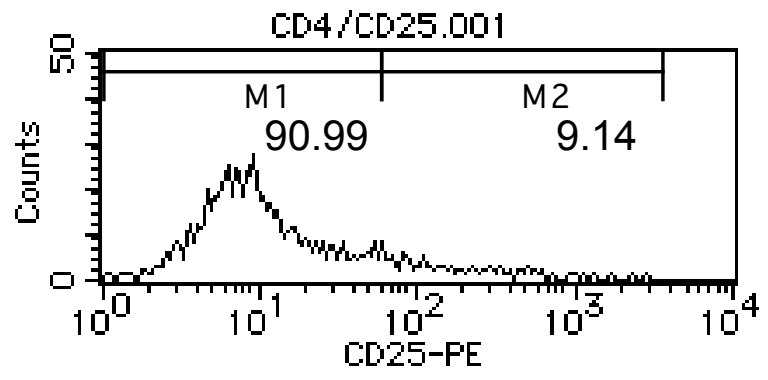

G

Treg(CD4 $\left.{ }^{+} \mathrm{CD}^{25^{+}}\right) / \mathrm{CD}^{+}$

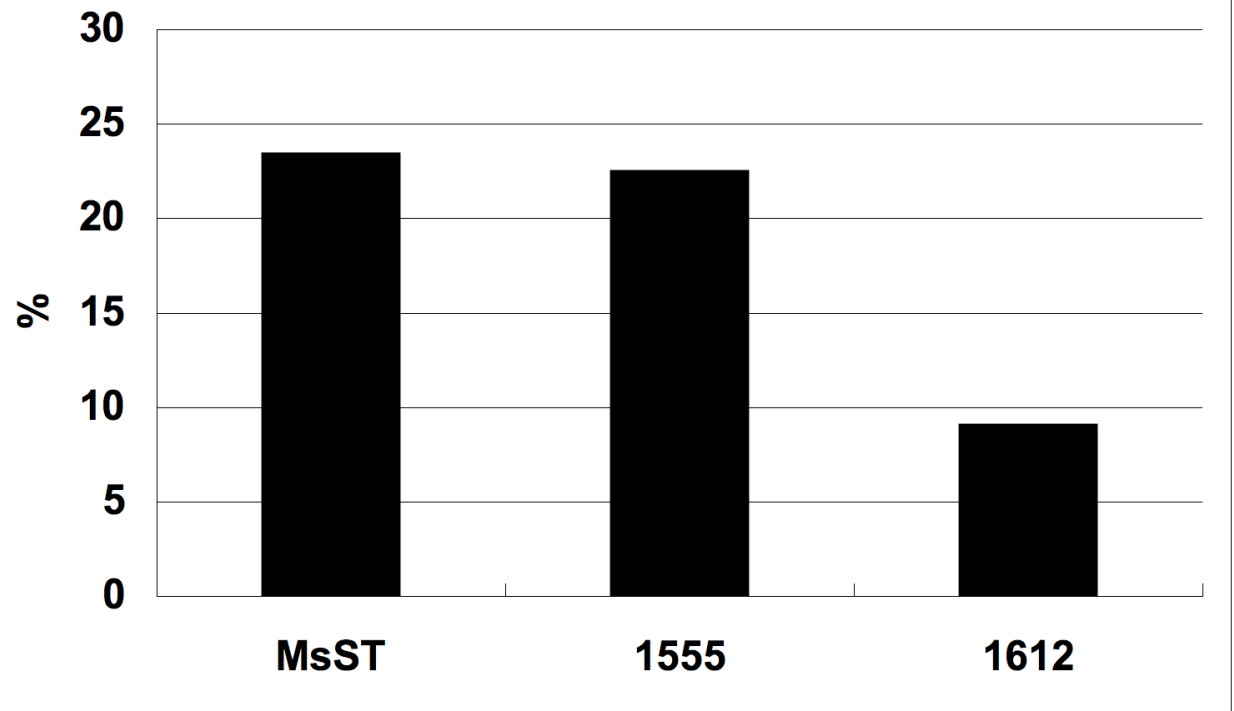


Fig.5

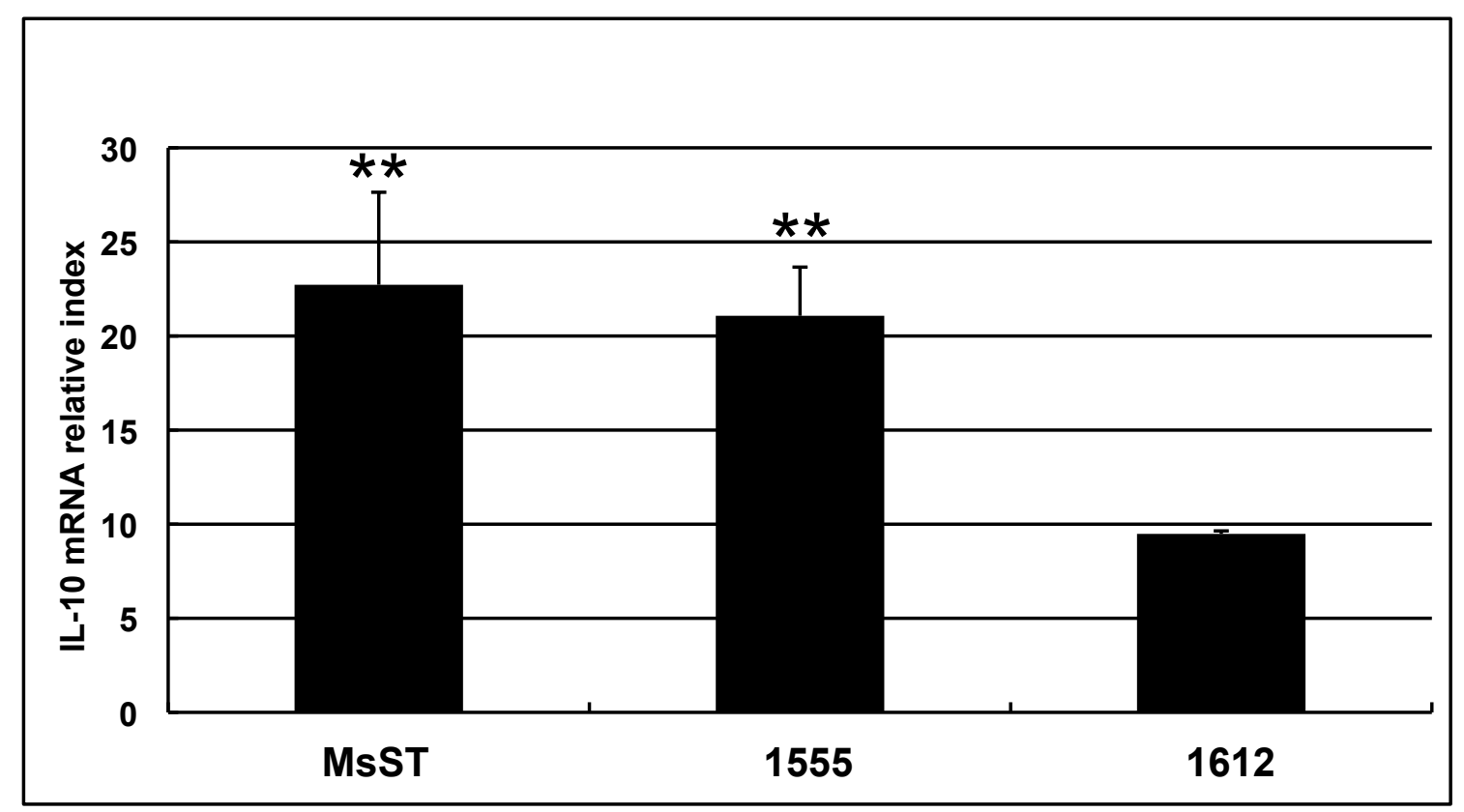

